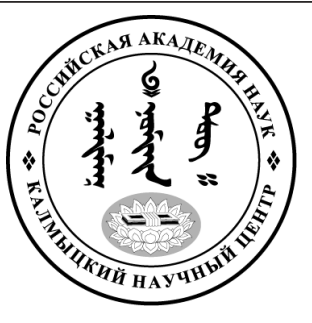

Published in the Russian Federation

Oriental Studies (Previous Name: Bulletin of the Kalmyk Institute

for Humanities of the Russian Academy of Sciences)

Has been issued as a journal since 2008

ISSN: 2619-0990; E-ISSN: 2619-1008

Is. 5, pp. 740-749, 2019

DOI: $10.22162 / 2619-0990-2019-45-5-740-749$

Journal homepage: https://kigiran.elpub.ru

УДК 94(47)+294.3

\title{
О документах, касающихся религии и ламства Монголии, из Центрального архива Федеральной службы безопасности Российской Федерации (1920-1930-е гг.)
}

\author{
Кеемя Владимировна Орлова ${ }^{1}$ \\ ${ }^{1}$ Институт востоковедения РАН (д. 12, ул. Рождественка, 107031 Москва, Российская Федерация) \\ ведущий научный сотрудник \\ ORCID: 0000-0003-4951-0063. E-mail: orlovnk@mail.ru
}

Аннотация. Цель статьи - дать характеристику некоторых архивных документов о религии и ламстве Монголии, которые хранятся в Центральном архиве Федеральной службы безопасности России (ЦА ФСБ РФ) в Москве и Управлении ФСБ России по Омской области и до недавнего времени были недоступны для исследователей. Материалы. Архивные документы включают специальные сообщения, шифрограммы, письма, сводки, обзоры политической, экономической, военной и религиозной ситуации в Монголии. Значительный массив документов относится к различным аспектам религиозной ситуации в Монголии в указанный период. В них освещаются такие вопросы, как реакция буддийского духовенства и его высших иерархов на политику МНРП и монгольского правительства, направленную на ограничение влияния буддийской церкви, монастырей, а также антиправительственные настроения, выступления и восстания $(1925,1930,1932$ и другие годы). Именно часть этих документов и будет в фокусе внимания данной статьи. Результатыл. Выявленные в ЦА ФСБ РФ документы наглядно показывают мероприятия в отношении религии и ламства в Монголии в указанный период. Репрессивные меры со стороны монгольской партии и правительства основательно подорвали главенствующую их роль в стране. Карательные меры по отношению к религии и ламству Монголии продолжались и на протяжении 1930-1940-х гг. Именно этот период характеризуется как время жесточайших репрессий против ламства.

Ключевые слова: Центральный архив ФСБ России, Монголия, буддизм, ламы, Тогсбуянтын хурээ, Чандмань-уул аймак

Для цитирования: Орлова К. В. О документах, касающихся религии и ламства Монголии, из Центрального архива Федеральной службы безопасности Российской Федерации (1920 1930-е гг.). Oriental Studies. 2019; (5): 740-749. DOI: 10.22162/2619-0990-2019-45-5-740-749. 
UDC 94(47)+294.3

\title{
Religion and Buddhist Clergy of Mongolia: Revisiting Documents from the Central Archive of the Federal Security Service of Russia (1920-1930s)
}

\author{
Keemya V. Orlova ${ }^{1}$ \\ ${ }^{1}$ Institute of Oriental Studies of the RAS (12, Rozhdestvenka St., Moscow 107031, Russian Federation) \\ Dr. Sc. (History), Cand. Sc. (Philology), Leading Research Associate \\ ORCID: 0000-0003-4951-0063. E-mail: orlovnk@mail.ru
}

\begin{abstract}
Goals. The article seeks to characterize some archival documents dealing with religion and Buddhist clergy of Mongolia and housed by the Central Archive of the Federal Security Service (FSB) of Russia (Moscow) and Omsk Oblast FSB Department, which have remained unavailable for research till recently. Materials. The archival papers include special reports, coded telegrams, letters, communiques, reviews of political, economic, military and religious conditions in Mongolia. Quite a share of the documents examine different aspects of Mongolia's religious affairs during the mentioned period. Those describe responses of the Buddhist clergy and clerical hierarchy to policies pursued by the Mongolian People's Party and the national government, and aimed to restrict the influence of the Buddhist church, monasteries; also depicted are responses of the former to antigovernment sentiments, disturbances and revolts $(1925,1930,1932$, etc.). The work actually focuses on the latter documents. Results. The papers discovered display- the measures undertaken towards Mongolia's religion and Buddhist clergy during the mentioned years. The repressions conducted by the MPP and government essentially undermined the leading positions of the latter. Punitive actions against religion and Buddhist priests would be launched throughout the 1930-1940s, and those were cruelest ones ever held in the country.

Keywords: Central Archive of the Federal Security Service of Russia, Mongolia, Buddhism, Buddhist clergy, Togsbuyantyn khüree, Chandmani Uul Aimag

For citation: Orlova K. V. Religion and Buddhist Clergy of Mongolia: Revisiting Documents from the Central Archive of the Federal Security Service of Russia (1920-1930s). Oriental Studies. 2019; (5): 740-749. DOI: 10.22162/2619-0990-2019-45-5-740-749.
\end{abstract}

\section{Введение}

В Центральном архиве ФСБ РФ и Управлении ФСБ России по Омской области группой монголоведов Института востоковедения РАН выявлено 163 документа, которые охватывают период с 1922 по 1936 гг., за исключением документов 1931 г. Связано это с тем, что материалы за этот год все еще находятся под грифом «секретно». За 1922 г. открыто 7 документов, за 1923 г. 21, за 1924 г. - 6, 1925 г. - 22, 1926 г. 4, 1927 г. - 4, 1928 г. - 29, 1929 г. - 14, 1930 г. - 18, 1932 г. - 3, 1933 г. - 2, 1934 - 1, 1935 - 25, 1936 г. - 7. Документы за эти годы рассекречены, часть из них дана в сокращении. Основная тематика архивных документов освещает межгосударственные отношения между СССР и МНР;
РКП(б)/ВКП(б), Коминтерном и МНРП; борьбу между «правыми» и «левыми» в правящей партии Монголии; политику МНРП и правительства в отношении религии и духовенства, антиправительственные настроения, выступления и вооруженные восстания.

Выявленные архивные материалы за указанный период относятся к первым годам после национально-демократической революции 1921 г., очень непростого и до сих пор спорного времени в истории советско/российско-монгольских отношений. В Монголии эта страница истории характеризуется становлением новой власти, коренным переустройством страны, сменой государственного строя, переходом сначала от абсолютной теократической формы 
правления к ограниченной монархии (19211924), затем - к республике (с 1924).

Цель статьи - дать характеристику некоторых архивных документов о религии и ламстве Монголии, которые хранятся в Центральном архиве Федеральной службы безопасности России (ЦА ФСБ РФ) в Москве и Управлении ФСБ России по Омской области и до недавнего времени были недоступны для исследователей.

\section{Основная часть}

1926 год в Монголии ознаменовался важными событиями: были приняты законы о едином налоге и об отделении церкви от государства. Согласно первому закону, от налогов освобождались бедные слои населения, государственным и кооперативным предприятиям предоставлялись льготы, а основную нагрузку возлагали на зажиточные слои населения и монастырские хозяйства. Принятие закона об отделении церкви от государства значительно ослабило положение церкви в стране, ликвидация института хубилганства по решению $\mathrm{V}$ съезда МНРП (сентябрь 1926 г.) стала знаковым событием. На съезде много внимания уделялось ламству и религии, не случайно в мае 1927 г. в Москву за № 155943 поступило информационное сообщение Восточного отдела ОГПУ под грифом «совершенно секретно» о прениях по ламскому вопросу (док. № 61). В нем, в частности, приводится стенограмма выступления Цыбена Жамцарано, где он озвучивает численность лам на 1927 г. - 115000 (при численности населения Монголии в 1920-х гг. примерно 700 800 тыс. чел. и 642 тыс. по переписи 1918 г. без учета жителей некоторых регионов ${ }^{1}$ ), a также поднимает вопрос принятия в партию исключительно «лучшей части ламства», и тех, кто «соглашается с целью и задачами $<\ldots>>$ партии», а «цель партии и основа религии одна и та же - помочь народной массе $<\ldots>$ объединиться для общей пользы». Жамцарано предложил разработать особое положение о ламах - членах партии, особенно для живущих в монастырях, «приспособив это положение к монашеским обетам» с освобождением их от военной службы [Архив УФСБ России по Омской области. Ф. 65. Д. 9920. Л. 10-12]. На этом

\footnotetext{
${ }^{1}$ Благодарю за устную информацию ученого секретаря Института истории и этнологии АН Монголии, проф. Н. Хишигт.
}

съезде разгорелись нешуточные прения делегатов, и они приводятся в следующем документе № 62, основную суть которых можно обобщить в следующем: привлекать их (т. е. лам) в свои союзники и через них вести работу среди всего ламства. Но вместе с тем отмечалась нецелесообразность привлечения всех лам в партию. Если одни делегаты выступали за единение ламства и партии, при этом призывая проявлять осторожность и осмотрительность при принятии в партию высших иерархов церкви и зажиточных лам, то другие считали, что лам нельзя привлекать к государственным делам, они должны заниматься только религиозными вопросами в соответствии с принятым законом [Архив УФСБ России по Омской области. Ф. 65. Д. 9920. Л. 18-20].

Необходимо отметить, что уничтожение ламства как сословия велось целенаправленно, в руководстве страны понимали, что именно эта часть населения имеет огромное влияние на своих соплеменников. Неслучайно вначале монгольские власти прибегали к склонению лам на свою сторону, в дальнейшем стали облагать непосильными налогами, насильственно переводить в мирян, запрещали принимать в монастыри малолетних детей, намеренно проводили политику расслоения лам. Распоряжение партии отлучить церковь от государственных и гражданских дел стало существенным фактором недовольства со стороны высших иерархов церкви. В последующие годы репрессивные меры в отношении религии и ламства только ужесточались.

Именно поэтому уже в 1928 г. появились сведения о попытке создания в Улангоме, аймачном центре Убсунурского (ныне Увс) аймака, либерально-клерикальной партии, хотя впервые информация о возможности появления такой партии возникла в 1926 г. на пленуме ЦК МНРП, когда среди делегатов пленума разгорелась дискуссия о создании в регионах «централизованного управления религиозными делами». Участники уже тогда сочли, что учреждение таких управлений приведет к созданию клерикальной партии [Рощин 1999: 144].

VII съезд МНРП (октябрь-декабрь 1928 г.) в своей резолюции принял радикальное решение конфисковать имущество и скот у монастырских хозяйств и крупных собственников, что в немалой степени повлияло на создание этой партии. Примеча- 
телен ответ присутствовавшего на съезде уполномоченного Коминтерна в Монголии М. И. Амагаева на вопрос одного из делегатов о возможности появления партии: «Организация такой партии недопустима, т. к. это даст возможность ламству найти крепкую организационную форму для консолидации своих разрозненных сил» [Архив УФСБ России по Омской области. Ф. 65. Д. 9920. Л. 184-185].

Следует учитывать еще один момент стремление буддийской церкви восстановить свою доминирующую роль во всех областях жизни общества - и в политической, и в экономической, и в культурной. Однако из обозначенной цели создания религиозной партии - «улучшить состояние религии путем борьбы с отрицательными явлениями в ламской жизни и замены старых руководителей более соответствующими духу современности и интересам религии» - вовсе не следует указанное выше, а лишь завуалированно преследовалось намерение реанимировать утерянные позиции ламства в стране [Архив УФСБ России по Омской области. Ф. 65. Д. 9920. Л. 184-185].

Судя по документу, инициатором создания такой партии был Ульзитийн Бадрах (1895-1941), дербет, выходец из сомона Давст Убсунурского аймака. Вначале он представлял худонскую оппозицию как выходец из Западной Монголии, затем стал одним из лидеров «левого» крыла партии, в 1928 г. занимал пост секретаря ЦК МНРП. Однако ламская либерально-клерикальная партия так и не была создана, ее задушили в зародыше, арестовав инициативную группу. Среди организаторов ламской организации значился арестованный брат У. Бадраха, лама Гунчин-Чойнджур, и другие. Видимо, арест зачинщиков должен был скомпрометировать Бадраха. Могу лишь предположить, что связано это было с жесткой борьбой «правой» оппозиции с «левой». На VII съезде партии «левое» крыло представляло собой несколько группировок, одну из которых - кобдоскую - возглавлял Бадрах. В документе № 94 об этом прямо говорится: группировка «представляет дербетское национальное движение, заражена автономистскими устремлениями и имеет свои частные интересы в оппозиционном («левом». $K$. O.) движении. До настоящего момента их интересы совпадали с интересами худонской группы, поскольку их устремления встреча- ли сопротивление со стороны центра. Худонскую ориентацию Бадрах видел в форме широкого местного самоуправления, вплоть до автономии отдельных аймаков, составляющих добровольный союз - нечто вроде Американских Соединенных Штатов» [Архив УФСБ России по Омской области. Ф. 65. Д. 140. Т. 4. Л. 142-158]. Возможно, «автономистские устремления» Бадраха и повлияли на его решение создать ламскую либерально-клерикальную партию как первый шаг к автономии западных аймаков Монголии. На это указывает дальнейшая линия к проведению автономизации западных аймаков. Так, в документе № 96 «Информационное сообщение о планах сторонников монгольской автономии относительно присоединения Синьцзяна к МНР» от 1 февраля 1929 г. сообщается: «Группа кобдоских автономистов (лидеры которых после VII съезда МНРП заняли ряд главенствующих постов в монгольском правительстве и ЦК МНРП, а именно Бадрах - один из секретарей ЦК, Лааган пред. ЦКК, Дэмбэрэл - секретарь Малого Хурулдана) выдвинула план усиления положения МНР на Востоке путем присоединения к МНР Синьцзяна» [ЦА ФСБ России. Ф. 2. Оп. 8. Д. 378. Л. 242-242об.], тем самым создать «объединенную Монголию» [Архив УФСБ России по Омской области. Ф. 65. Д. 140. Т. 4. Л. 211-212об.].

Ограничение влияния религии в стране прослеживается и по другим архивным документам. В 1929 г. ламы монастыря Гандантэгчинлин совершенно определенно высказывались о жестком наступлении на религию, один из них образно сравнил «разбитую фарфоровую чашу с религией, как $<\ldots>$ изжившую свое существование и пригодность». При этом однозначно конкретизировалась цель монгольской партии и правительства - «уничтожение ламства и религии, < . >> а все мероприятия, направленные против религии, проводятся под диктовку красных русских» [Архив УФСБ России по Омской области. Ф. 65. Д. 9920. Л. 262-264].

В 1930 г. ситуация еще более усугубилась: помимо налога на джасу르, лам призывного возраста обязали платить еще военный налог и налог худону로. В проекте правитель-

2 Джаса (монг. жас) - с середины XVII в. накопления и хозяйство монашеской общины буддийских монастырей Монголии.

${ }^{3}$ Худон (монг. хөдөө) - сельская местность. 
ство планировало ввести еще налог на хашаны ${ }^{4}$ и постройки. Делалось это для того, чтобы ламы как можно скорее покидали монастыри и переходили в светское состояние [ЦА ФСБ России. Ф. 2. Оп. 8. Д. 307. Л. 9-13об.]. Не напрасно религиозные деятели опасались ужесточения налоговой политики: уже в мае 1929 г. на пленуме ЦК МНРП обсуждался вопрос о передаче имущества, скота ванов, гунов, высших иерархов церкви - хутухт и хубилганов - аратам-беднякам, для чего в срочном порядке создавались артели, колхозы, госхозы. На пленуме выявились разные подходы к этой проблеме: один - умеренный, или «осторожный», подход - экономическими методами (прогрессивным налогообложением; ограничением круга тех, у кого будет изыматься конфискуемое, и размеров изъятия имущества и скота), другой - радикальный, т. е. жесткая конфискация [Рощин 1999: 226].

В результате ЦК монгольской партии решил, что широкое наступление на монастыри и лам крайне опасно и нежелательно. Понятно, что высшие ламы не питали иллюзий относительно проводимой политики, они отчетливо понимали, что «заложен фундамент для ликвидации ламства, a <..> после VIII съезда эта ликвидация будет проводиться в жизнь форсированным темпом» [Архив УФСБ России по Омской области. Ф. 65. Д. 9920. Л. 332-341]. Партийными функционерами учитывалось прежде всего имущественное положение монгольских лам: «в имущественном положении - у населения 4498357 бодо 5 и у монастырей (джас) 842280 бодо, что составляет 17,84 \%. Простое соотношение цифр бодо у населения и джас таково: на каждого светского едока приходится 7,2 бодо, а на каждого едока-ламу - 8 бодо. В количество бодо не входит денежный капитал монастырских джас, используемый ламством с ростовщической целью (проценты частных ссуд достигают до 50-60 годовых). При прогрессивном обложении джас налоги с них составляют 27,7 \% по отношению к общей сумме налога с населения. Эти цифры, подтверждая сказан-

\footnotetext{
${ }^{4}$ Хашан (монг. хамаан) - забор, загон для скота, двор, подворье.

${ }^{5}$ Бодо (монг. бод) - условная единица учета скота; 1 бодо равен 1 корове, 1 лошади, двум верблюдам, пяти овцам, семи козам.
}

ное выше, наводят на вопрос о состоянии ламства на местах». Относительно численности лам в том же 1930 г. отмечалось: «в пяти аймаках МНР (в документе не указано, какие аймаки Монголии. - $K$. O.) светских мужчин 260 905, женщин 345 350, итого светского населения 617 843, плюс лам 104 106, всего населения 721 949. Таким образом, 16,83 \% всего населения, или почти 40 \% всех мужчин, состоит из «нетрудовых паразитических элементов лам» [Архив УФСБ России по Омской области. Ф. 65. Д. 9920. Л. 350-365]. Простой подсчет численности мужчин и женщин показывает досадную ошибку в документе на 11588 человек, соответственно и общей численности населения и светских, и лам - 710 361, а не как указано в документе - 721 949. Даже при ошибке подсчета численности населения значительную часть монгольского населения составляло именно ламское сословие.

В 1930 г. положение лам еще более ухудшается, о чем свидетельствуют сами служители: «хуралы проходят с большими перебоями», из-за конфискации имущества богатых лам фактически прекратились пожертвования монастырям. Но более всего удручало высших лам, что, согласно постановлению правительства, отныне их представители будут обучать грамоте молодых послушников, а это означало, что «они, во всяком случае, не будут ограничиваться преподаванием языка, а будут стараться вдолбить в головы хувараков идеи невыгодности посвящения себя в духовное звание» [Архив УФСБ России по Омской области. Ф. 65. Д. 9920. Л. 332-341. Заверенная копия].

Однако не все гладко было как внутри ламской общины, так и среди населения. Показательны в данном случае выступления делегатов VIII съезда МНРП (февраль 1930 г.). Так, некий Будбазар (делегат из Цэцэрлэга) высказался конкретно: «Для борьбы с религией и ликвидации ее необходимо провести следующие мероприятия: во-первых, усилить агитационную работу среди бедняцких аратских масс, во-вторых, категорически воспретить дачу детей в ламы до 18 лет, в-третьих, при коммунах и на местах организовать европейские фельдшерские пункты, в-четвертых, увеличить обложение налогом имущества монастырских джас, и, кроме того, с лам призывного возраста взимать специальные налоги» [Архив УФСБ России по Омской области. 
Ф. 65. Д. 9920. Л. 427-432]. Эти мероприятия постепенно внедрялись в жизнь, что не замедлило вылиться в восстания и выступления не только лам, но и монгольского мирского населения, прежде всего, западных регионов Монголии.

Одно из крупных выступлений произошло в монастыре Тогсбуянт (Дашжугнэй) Чандмань-уульского (ныне Убсунурского; монг. Увс) аймака в 1930 г. Монастырь основан в 1879 г. у реки Дэлгэр в хошуне дербетского Далай-хана, разгромлен в 1938 г. В 1929 г. в монастыре числилось 1150 лам, из которых в 1932 г. в светское состояние перешли 690 человек [Думбурай 2002: 8].

В октябре 1929 г. состоялся VI аймачный партийный съезд, в резолюции которого отмечалось «решительное прекращение участия ламства в хозяйственной жизни», запрет несовершеннолетним (до 18 лет) поступать в монастыри. Уже через месяц, в ноябре того же года, пленум аймачного управления подтвердил решение съезда: «решительно прекратить всякое участие ламства, остатков черно-желтых харгисов ${ }^{6}$, новой и старой буржуазии в хозяйственноэкономической жизни населения и кабальной эксплуатации последнего; прекратить посвящение в ламство несовершеннолетних до 18-ти лет и $<\ldots>$ отдавать их в школу для обучения языку и письменности» [Архив УФСБ России по Омской области. Ф. 65.
Д. 9920. Л. 554-575]. В решении аймачного управления жестко оговаривались сроки исполнения - немедленно приступить к исполнению, «поскольку эти мероприятия имеют громадное значение в хозяйственно-экономической жизни аратского населения» [Архив УФСБ России по Омской области. Ф. 65. Д. 9920. Л. 554-575].

Циркуляры в сомонные управления поступали регулярно: о принудительном вовлечении бедняцко-середняцкого аратства в колхозы; об отлучении лам от уртонной службы, о запрещении заниматься в монастырях столярно-кузнечным ремеслом, выселении из монастырей несовершеннолетних, а «запрещение земледелия и торговли явилось таким ударом, который для ламства $<\ldots>$ был равносилен запрещению питаться вообще, ибо это запрещение било по жизненным экономическим интересам как зажиточной ламской верхушки (лишение основного источника дохода), так и особенно ламской бедноты, которая лишилась источника существования» [Архив УФСБ России по Омской области. Ф. 65. Д. 9920. Л. 554-575].

Чтобы наглядно продемонстрировать положение ламства, приведу данные по хошунным монастырям Чандмань-уульского аймака - см. таблицы 1 и 2 [Архив УФСБ России по Омской области. Ф. 65. Д. 9920. Л. 554-575].

\section{Таблица 1. Данные по хошунным монастырям Чандмань-уул аймака}

[Table 1. Khoshuu (district)-level monasteries of Chandmani Uul Aimag: statistics]

\begin{tabular}{|c|c|c|c|c|c|c|c|c|}
\hline $\begin{array}{l}\text { № } \\
\Pi / \Pi\end{array}$ & Хошуны & $\begin{array}{c}\text { Наименование } \\
\text { монастырей }\end{array}$ & $\begin{array}{l}\text { Коли- } \\
\text { чество } \\
\text { лам }\end{array}$ & $\begin{array}{c}\text { Из них } \\
\text { до } 18 \text { лет }\end{array}$ & $\begin{array}{l}\text { Перешед. } \\
\text { в/ч сост. }\end{array}$ & $\begin{array}{l}\text { Коли- } \\
\text { чество } \\
\text { джас: }\end{array}$ & $\begin{array}{l}\text { Количе- } \\
\text { ство хуби } \\
\text { в дж. }\end{array}$ & $\begin{array}{l}\text { Приме- } \\
\text { чание }\end{array}$ \\
\hline \multirow[t]{2}{*}{1.} & $\begin{array}{l}\text { Баин- } \\
\text { Чанд- } \\
\text { мань }\end{array}$ & $\begin{array}{l}\text { 1. Улангом } \\
\text { 2. Намир } \\
\text { 3. Найдан } \\
\text { 4. Кобдоск. хурэ } \\
\text { 5. Лайджан } \\
\text { 6. Шарчихэ }\end{array}$ & $\begin{array}{l}1450 \\
200 \\
141 \\
\\
146 \\
44 \\
294\end{array}$ & $\begin{array}{c}503 \\
80 \\
40 \\
\\
41 \\
20 \\
92\end{array}$ & $\begin{array}{c}286 \\
- \\
- \\
- \\
- \\
-\end{array}$ & $\begin{array}{c}45 \\
30 \\
20 \\
\\
16 \\
2 \\
13\end{array}$ & $\begin{array}{c}10284 \\
491 \\
1637 \\
\\
1887 \\
406 \\
468\end{array}$ & \\
\hline & Итого: & & 2275 & 776 & 286 & 126 & 15169 & \\
\hline \multirow[t]{2}{*}{2.} & $\begin{array}{l}\text { Тогс- } \\
\text { Буянт: }\end{array}$ & $\begin{array}{l}\text { 1. Дашиджонайлин } \\
\text { 2. Бадмасамбава }\end{array}$ & $\begin{array}{c}1203 \\
117\end{array}$ & $\begin{array}{c}563 \\
21\end{array}$ & $\begin{array}{c}358 \\
-\end{array}$ & $\begin{array}{c}126 \\
2\end{array}$ & $\begin{array}{c}15729 \\
1269\end{array}$ & взр. 81 ч. \\
\hline & Итого: & & 1320 & 584 & 358 & 128 & 16998 & \\
\hline
\end{tabular}

${ }^{6}$ Т. е. реакционеров.

${ }^{7}$ Означает «Перешло единиц в «черное» (т. е. светское) состояние 
Oriental Studies. 2019. Is. 5

\begin{tabular}{|c|c|c|c|c|c|c|c|c|}
\hline $\begin{array}{c}\text { № } \\
\Pi / \Pi\end{array}$ & Хошуны & $\begin{array}{c}\text { Наименование } \\
\text { монастырей }\end{array}$ & $\begin{array}{l}\text { Коли- } \\
\text { чество } \\
\text { лам }\end{array}$ & $\begin{array}{c}\text { Из них } \\
\text { до } 18 \text { лет }\end{array}$ & $\begin{array}{l}\text { Перешед. } \\
\text { в/ч сост. }\end{array}$ & $\begin{array}{l}\text { Коли- } \\
\text { чество } \\
\text { джас: }\end{array}$ & $\begin{array}{l}\text { Количе- } \\
\text { ство хуби } \\
\text { в дж. }\end{array}$ & $\begin{array}{l}\text { Приме- } \\
\text { чание }\end{array}$ \\
\hline \multirow[t]{2}{*}{3.} & $\begin{array}{l}\text { Баян- } \\
\text { Мандал }\end{array}$ & $\begin{array}{l}\text { 1. Дэджэлин } \\
\text { 2. Цалгар }\end{array}$ & $\begin{array}{c}1111 \\
270\end{array}$ & $\begin{array}{c}251 \\
50\end{array}$ & $\begin{array}{c}202 \\
50\end{array}$ & $\begin{array}{c}15 \\
6\end{array}$ & $\begin{array}{c}1776 \\
386\end{array}$ & $\begin{array}{c}\text { Вар/ } \\
\text { молод. } \\
\text { выселена } \\
\text { отс. } 49 \text { ч. }\end{array}$ \\
\hline & Итого: & & 1371 & 301 & 252 & 21 & 2162 & \\
\hline \multirow[t]{2}{*}{4.} & $\begin{array}{l}\text { Наран- } \\
\text { Хайрхан: }\end{array}$ & $\begin{array}{l}\text { 1. Тугэмэл-Амаржиг } \\
\text { 2. Тэгмид-дацан } \\
\text { 3. Гун-Хотон } \\
\text { 4. Цаганнасун-дацан } \\
\text { 5. Дзоми } \\
\text { 6. Кобдоское хурэ }\end{array}$ & $\begin{array}{c}147 \\
106 \\
122 \\
63 \\
139 \\
343 \\
\end{array}$ & $\begin{array}{l}46 \\
68 \\
53 \\
39 \\
91 \\
99\end{array}$ & $\begin{array}{l}- \\
- \\
- \\
- \\
91 \\
-\end{array}$ & $\begin{array}{l}2 \\
5 \\
6 \\
1 \\
4 \\
4\end{array}$ & $\begin{array}{c}534 \\
346 \\
314 \\
23 \\
116 \\
373 \\
\end{array}$ & \\
\hline & Итого: & & 920 & 396 & 91 & 22 & 1706 & \\
\hline \multirow[t]{2}{*}{5.} & $\begin{array}{l}\text { Хан- } \\
\text { Батор }\end{array}$ & $\begin{array}{l}\text { 1. Заргын-хурэ } \\
\text { 2.Тугруг } \\
\text { 3. Цаган-Бурасон } \\
\text { 4. Бодонч }\end{array}$ & $\begin{array}{l}484 \\
171 \\
184 \\
302 \\
\end{array}$ & $\begin{array}{c}352 \\
46 \\
38 \\
70 \\
\end{array}$ & $\begin{array}{c}253 \\
- \\
- \\
- \\
\end{array}$ & $\begin{array}{c}6 \\
4 \\
2 \\
10\end{array}$ & $\begin{array}{c}3244 \\
1687 \\
839 \\
2372 \\
\end{array}$ & $\begin{array}{c}50 \% \\
\text { молоде- } \\
\text { жи }\end{array}$ \\
\hline & Итого: & & 1141 & 506 & 253 & 22 & 8142 & \\
\hline \multirow[t]{2}{*}{6.} & $\begin{array}{l}\text { Булган- } \\
\text { Мандал } \\
\text { (торгоут }\end{array}$ & $\begin{array}{l}\text { 1. Хошун-хурэ } \\
\text { 2. Бейлэ-хурэ } \\
\text { 3. Тайджинар } \\
\text { 4. Улясутай } \\
\text { 5. Уенч }\end{array}$ & $\begin{array}{c}50 \\
170 \\
67 \\
50 \\
200 \\
\end{array}$ & $\begin{array}{l}- \\
- \\
- \\
- \\
-\end{array}$ & $\begin{array}{l}- \\
- \\
- \\
- \\
-\end{array}$ & $\begin{array}{l}- \\
- \\
- \\
- \\
-\end{array}$ & $\begin{array}{l}- \\
- \\
- \\
- \\
-\end{array}$ & \\
\hline & Итого: & & 537 & - & - & - & - & \\
\hline \multirow[t]{3}{*}{7.} & $\begin{array}{l}\text { Алтай- } \\
\text { Ханул }\end{array}$ & $\begin{array}{l}\text { 1. Чингил-Хайрхан. } \\
\text { 2. Харгантын-хурэ } \\
\text { 3. Сагсын-гол хурэ } \\
\text { 4. Дэлюн-гол } \\
\text { 5. Астанцогт } \\
\text { 6. Тэмуртуйн хурэ } \\
\text { 7. Худжирт }\end{array}$ & $\begin{array}{c}51 \\
18 \\
317 \\
133 \\
120 \\
231 \\
327\end{array}$ & $\begin{array}{l}- \\
- \\
- \\
- \\
- \\
- \\
-\end{array}$ & $\begin{array}{l}- \\
- \\
- \\
- \\
- \\
- \\
-\end{array}$ & $\begin{array}{l}- \\
- \\
- \\
- \\
- \\
- \\
-\end{array}$ & $\begin{array}{c}484 \\
32 \\
3612 \\
800 \\
1286 \\
1904 \\
3934\end{array}$ & \\
\hline & Итого: & & 1257 & - & - & - & 12524 & \\
\hline & Всего: & 32 монастыря & 8761 & 2563 & 1240 & 319 & 56229 & $\begin{array}{c}48 \% \\
\text { монгол }\end{array}$ \\
\hline
\end{tabular}

В таблице 1 некорректно указаны ламы до 18 лет - 2563 человек, нет данных по хошунам Булган-Мандал и Алтай-Ханул, то же самое касается перешедших в черное (светское) состояние, количества джасы и хуби в джасах, хотя в примечании отмечено, что цифры не полные.

\section{Таблиия 2. Данные по ламам в монастырях в 7 хошунах Чандмань-уул аймака}

[Table 2. Buddhist clergy of the 7 khoshuu-level monasteries of Chandmani Uul Aimag: statistics]

\begin{tabular}{|l|c|c|c|}
\hline \multicolumn{1}{|c|}{ Хошуны: } & Взрослые ламы & Несовершеннолетние до 18 лет & \% малолетних $^{8}$ \\
\hline 1. Баян-Чандмань & 2275 & 776 & 25,4 \\
2. Баян-Мандал & 1371 & 301 & 18 \\
3. Тогс-Буянт & 1320 & 584 & 30,6 \\
4. Наран-Хайрхан & 920 & 396 & 30 \\
5. Хан-Батор & 1141 & 506 & 30,7 \\
6. Булган-Мандал & 537 & - & - \\
7. Алтай-хан & 1257 & - & 22,5 \\
\hline \multicolumn{1}{|c|}{ Итого: } & 8821 & $2653(2553)$ & \\
\hline
\end{tabular}

${ }^{8}$ В документе подсчет малолетних в процентах не приводится. Подсчитано мной. - K. $O$. 
Данные по несовершеннолетним (до 18 лет) подсчитаны некорректно, должно быть 2 563. По двум хошунам - Булган-Мандал и Алтай-хан — численность несовершеннолетних не указана. Как видно из таблицы, процент несовершеннолетних 22,5 , опять же без учета двух хошунов (Булган-Мандал и Алтай-хан).

Гонения на религию и ламство не замедлили сказаться. 25 марта 1930 г. повстанцы (40 лам) арестовали глав хошунных учреждений и обратились к населению с призывом оказать помощь. Основные лозунги, которые выдвигали повстанцы: «долой МНР», «долой конфискацию феодалов и ламства», «долой выселение до 18-ти лет», «долой призыв 33-летних как мобилизацию сил против ламства и религии», «присоединение церкви к государству», «восстановление прежних приношений ламству», «долой партию бедняков, середняков-аратов, да здравствует социально-равная партия〉 [Архив УФСБ России по Омской области. Ф. 65. Д. 9920. Л. 554-575].

Отклик со стороны местного населения последовал сразу же, был организован отряд численностью 200 человек, куда вошли в основном ламы из монастыря Тогсбуянт и простые араты. Повстанцы решили образовать двухпалатное правительство по 20 человек в каждом - от лам и феодалов и аратов, а также упразднили прежнюю систему управления. Однако их замыслам помешали последовавшие по горячим следам мгновенные решения монгольского правительства. $\mathrm{B}$ помощь прежнему руководству аймака был выслан отряд, который уже 30 марта подошел к стенам монастыря, начал его обстреливать и предъявил ультиматум повстанцам: сдаться, выдать зачинщиков мятежа, освободить арестованных хошунных начальников. Всего лишь через час повстанцы сдались.

Операцию по подавлению восстания провели сотрудники Государственной внутренней охраны МНР. Как указано в документе, бой продолжался всего 12 часов, основными причинами неудачного мятежа послужили отсутствие опыта ведения боевых действий, «стихийное выступление лам», отсутствие компетентных и грамотных в военном отношении специалистов и плохое вооружение (порой ламы и поддерживавшие их араты были оснащены лишь «дубин- ками»). В результате потери лам оказались значительными для монастыря Тогсбуянт: 19 лам и 20 светских лиц расстреляли уже 3 апреля; заключены в тюрьмы 33 человека (15 лам и 18 светских лиц), условно осуждены и впоследствии амнистированы 86 человек (81 лам, 5 аратов).

Имущественное состояние расстрелянных было следующим: имеющих от 1 до 20 хуби ${ }^{9}$ - двое лам, зажиточных светских лиц - нет, аратов - 4; от 21 до 50 хуби семеро лам, светских - двое, аратов трое; имеющих от 50 до 100 хуби - двое лам, светских - нет и аратов - двое; имеющих свыше 100 хуби: лам — от 8 до 14 человек, светских - от 7 до 9, аратов - от двух до 11. То есть имеющих от 1 до 20 хуби в восстании приняли участие всего шестеро человек, от 21 до 50 хуби - 12, от 50 до 100 хуби - четверо и имеющих свыше 100 хуби - от 17 до 39 человек [Архив УФСБ России по Омской области. Ф. 65. Д. 9920. Л. 554-575].

Необходимо отметить, что только в монастыре Тогсбуянт произошло восстание лам, хотя к мятежу были готовы и ламы из монастыря Бухморин и Бодончи. Однако репрессивные меры со стороны монгольского правительства и быстрое подавление восстания в монастыре Тогбуянт охладили пыл повстанцев из этих монастырей. Созданная комиссия по расследованию причин восстания в монастыре Тогсбуянт и неосуществившихся мятежей в монастырях Бухморин и Бодончи среди главных отметила: принудительное выселение послушников до 18 лет, не распространив отмену на уже выселенных; запрещение заниматься земледелием; принудительное вовлечение аратов в колхозы; взимание повинностей с населения для обеспечения пограничных цагд [Архив УФСБ России по Омской области. Ф. 65. Д. 9920. Л. 554-575].

\section{Заключение}

Таким образом, выявленные из Центрального архива ФСБ РФ документы наглядно показывают мероприятия в отношении религии и ламства в Монголии в указанный период. Репрессивные меры со стороны монгольской

\footnotetext{
9 Хуби (монг. хувь) - доля, пай; условная счетная налоговая единица, равная 30 тугрикам применительно к скоту и 90 тугрикам — к недвижимому имуществу.
} 
партии и правительства основательно подорвали главенствующую их роль в стране. Карательные меры по отношению к религии и ламству Монголии продолжались и на протяжении 1930-1940-х гг. Именно этот период характеризуется как время жесточайших репрессий против ламства. К 1938 г. из 771 монастыря были закрыты 615 (оставшиеся закрыли позже), а «из шести тысяч арестованных лам выжило незначительное число» без учета погибших в 1928-1932 и 1937-1938 гг. [Сабиров 2012: 96]. К 1940-м гг. в «МНР ламство как многотысячное могущественное сословие перестало существовать» [История Монголии 2007: 103].

\section{Источники \\ ЦА ФСБ России - Центральный архив ФСБ России:}

Информационное сообщение о планах сторонников монгольской автономии относительно присоединения Синьцзяна к МНР // Ф. 2. Оп. 8. Д. 378. Л. 242-242об. Машинописная копия.

Информационное сообщение ИНО ОГПУ о ламских настроениях // Ф. 2. Оп. 8. Д. 307. Л. 9-13об. Подлинник.

Архив УФСБ России по Омской области - Apхив УФСБ России по Омской области:

Информационное сообщение Восточного отдела ОГПУ о прениях по ламскому вопросу на V съезде МНРП // Ф. 65. Д. 9920. Л. 10-12. Заверенная копия.

Информационное сообщение Восточного отдела ОГПУ о прениях по ламскому вопросу на V съезде МНРП. Приложение // Ф. 65. Д. 9920. Л. 18-20. Заверенная копия.

Из информационного сообщения о политической ситуации в МНР за октябрь - ноябрь 1928 г. // Ф. 65. Д. 140. Т. 4. Л. 142-158. Машинописная копия.

Информационное сообщение о планах монгольских сторонников автономии относительно присоединения Синьцзяна к МНР // Ф. 65. Д. 140. Т. 4. Л. 211-212об. Машинописная копия.

Информационное сообщение о попытке организации ламской либерально-клерикальной партии. Приложение // Ф. 65. Д. 9920. Л. 184-185. Заверенная копия.

Информация ОО ОГПУ БМР по Монголии (по состоянию на сентябрь 1929 г.). Приложение // Ф. 65. Д. 9920. Л. 262-264. Заверенная копия.

Информационное сообщение о ламстве при правом руководстве МНРП. Приложение // Ф. 65. Д. 9920. Л. 350-365. Заверенная копия.
Информационное сообщение о настроениях делегатов VIII съезда МНРП // Ф. 65. Д. 9920. Л. 427-432. Заверенная копия.

Информационное сообщение Облотдела ОГПУ БМР о настроениях в среде ламства. Приложение // Ф. 65. Д. 9920. Л. 332-341. Заверенная копия.

Доклад начальника ГВО МНР Б.-О. ЭлдэвОчира о ликвидации контрреволюционного восстания ламства и феодалов в Северо-Западной Монголии (10 мая 1930 г.) // Ф. 65. Д. 9920. Л. 554-575. Заверенная копия.

\section{Sources \\ Central Archive of the Federal Security Service of Russia:}

[Plans of Mongolian Autonomy Proponents about Annexation of Xinjiang to the Mongolian People's Republic] (information report). Fond 2. Ser. 8. File 378. P. 242. Typed copy. (In Russ.)

[Sentiments among the Buddhist Clergy] information report of Foreign Affairs Department, Joint State Political Directorate / OGPU). Fond 2. Ser. 8. File 307. Pp. 9-13. Original document. (In Russ.)

Archive of Omsk Oblast FSB Department:

[Debates on the Issue of Buddhist Clergy at the $5^{\text {th }}$ MPP Congress] (information report of Oriental Department, OGPU). Fond 65. File 9920. Pp. 10-12. Certified copy. (In Russ.)

[Debates on the Issue of Buddhist Clergy at the $5^{\text {th }}$ MPP Congress] (information report of Oriental Department, OGPU; supplement). Fond 65. File 9920. Pp. 18-20. Certified copy. (In Russ.)

[Political situation in the MPR: October-November 1928] (excerpt from information report). Fond 65. File 140. Vol. 4. Pp. 142-158. Typed copy. (In Russ.)

[Plans of Mongolian Autonomy Proponents about Annexation of Xinjiang to the MPR] (information report). Fond 65. File 140. Vol. 4. Pp. 211-212. Typed copy. (In Russ.)

[An Attempt of Establishing a Lamaist Liberaland-Clerical Party] (information report). Fond 65. File 9920. Pp. 184-185. Certified copy. (In Russ.)

[Situation in Mongolia: as of September 1929] (information report of Buryat-Mongolian Regional OGPU Department; supplement). Fond 65. File 9920. Pp. 262-264. Certified copy. (In Russ.)

[Buddhist Clergy Affiliated to the Right Wing of the MPP's Leadership] (information report; supplement). Fond 65. File 9920. Pp. 350-365. Certified copy. (In Russ.)

[Sentiments among Party Delegates to the $8^{\text {th }}$ MPP Congress] (information report). Fond 65. File 9920. Pp. 427-432. Certified copy. (In Russ.) 
[Sentiments among the Buddhist Clergy] (information report of Buryat-Mongolian Regional OGPU Department; supplement). Fond 65. File 9920. Pp. 332-341. Certified copy. (In Russ.)

[Suppression of a Counterrevolutionary Revolt Initiated by the Clergy and Feudalists in Northwestern Mongolia] (report by B.-O. Eldev-Ochir, Head of the MPR's State Homeland Security Service; May 10, 1930). Fond 65. File 9920. Pp. 554-575. Certified copy. (In Russ.)

\section{Литература}

Буддийская традиция 2015 - Буддийская традиция в Калмыкии и Западной Монголии: сакральные объекты / Э. П. Бакаева, К. В. Орлова, Н. Хишигт, Ц. Энхчимэг. М.: Наука; Вост. лит., 2015. 238 с.

Думбурай 2002 - Думбурай А. Увс аймгийн хүрээ хийд ба түүний лам нарын хувь заяа (Түүхэн тэмдэглэл) (= Монастыри Убсунурского аймака и судьбы его монахов (исторические записи). Улаанбаатар, 2002. 44 х.

История Монголии 2007 - История Монголии. ХХ век. М.: ИВ РАН, 2007. 448 с.
Рощин $1999-$ Рощин С. К. Политическая история Монголии (1921-1940 гг.). М.: ИВ РАН, 1999. $327 \mathrm{c}$.

Сабиров 2012 - Сабиров Р. Т. Буддизм в Монголии на рубеже XX-XXI вв. // Вестник КИГИ PAH. 2012. № 3. C. 95-100.

\section{References}

[History of Mongolia: 20 $0^{\text {th }}$ Century]. Moscow: Institute of Oriental Studies (RAS), 2007. 448 p. (In Russ.)

[The Buddhist Tradition in Kalmykia and Western Mongolia: Sacred Objects]. E. P. Bakaeva, K. V. Orlova, N. Khishigt, Ts. Enkhchimeg. Moscow: Nauka; Vost. Lit., 2015. 238 p. (In Russ.)

Dumburay A. [Monasteries of Uvs Aimag and Destinies of Its Monks: Historical Notes]. Ulaanbaatar, 2002. 44 p. (In Mong.)

Roshchin S. K. [Political History of Mongolia: 1921-1940]. Moscow: Institute of Oriental Studies (RAS), 1999. 327 p. (In Russ.)

Sabirov R. T. Buddhism in Mongolia at the turn of the $21^{\text {st }}$ century. Bulletin of the Kalmyk Institute for Humanities of the RAS. 2012. No. 3. Pp. 95100. (In Russ.) 